\title{
Web-Based GIS for Safe Shipping in Istanbul Bosphorus Strait
}

\author{
Mustafa Umit GUMUSAY
}

\begin{abstract}
The term "shipping accident" is mostly used to define any accident occurring at sea resulting in financial loss, including life or property or both. Common shipping accidents can be categorized into several groups: collision or contact, capsize, foundering, breaking-up, grounding, breakdown of the ship, underway, stranding and fire or explosion. Common shipping accidents in the strait of Istanbul are mostly collisions or stranding. Providing the necessary information for safe shipping in the strait could decrease shipping accidents. That kind of accurate information is generally achieved through navigation systems. Web-based GIS is one type which contributes to these navigation systems. Web-based GIS is a network-based tool that takes advantage of the internet, with the visualizing, analysing and accessing of distributed data and analysis functions. This study is aimed at creating a Web-based GIS application for effective coastal management, which includes berthing factors (anchorage areas, currents, submerged, etc.), maritime traffic factors (traffic separation schemes, traffic flow directions), closed areas and other factors (lighthouses, buoys, beacons, etc.) by digitizing printed navigation charts produced by the Turkish Naval Forces' Office of Navigation, Hydrography and Oceanography. Such an application could be widely used as it is web-based. The system is expected to contribute not only to the accurate navigation of high-tonnage ships but also to smaller vessels that do not have their own navigation systems.
\end{abstract}

Keywords: Bosphorus; Photograph; Shipping Accidents; Web-Based GIS

\section{INTRODUCTION}

The strait of Istanbul connects the Black Sea to the Aegean Sea. It is crucial and is one of the narrowest waterways which separates the European and Asian continents (Fig. 1). The strait of Istanbul has an inevitable role in oil transportation, since it links the Black Sea and the Mediterranean Sea. Istanbul Strait's bottom topography shows plenty of banks, holes and shallows, as well as sinks. As a result, it has been a busy and risky waterway, like the Malaka Strait. The strait of Istanbul is considered very special with its geographical, hydrographical, oceanographic and meteorological importance. It is about $31 \mathrm{~km}$ long and $1.5 \mathrm{~km}$ wide. With its length and width, it is not only one of the most important and narrowest straits of the world but also has more than ten sharp turns [1]. Its width between Kandilli and Bebek is a mere $698 \mathrm{~m}$ [2]. The Bosphorus is one of most important natural straits in the world, handling 150 transit ships, 23 freighters with dangerous cargo and 2500 local transport ships with 2 million passengers on a daily basis. This makes it one of the most perilous and congested waterways in the world [3]. Thus, shipping navigation becomes risky, leading to numerous different types of marine accidents [4]. The impact of accidents on the marine environment is explicitly different to each other. Common shipping accident can be categorized into several groups; collision or contact, capsize, foundering, breaking-up, grounding, breakdown of the ship, underway, stranding and fire or explosion [5]. As a result of such accidents at sea, there has been some financial loss, environmental pollution and casualties. Maritime accidents have inevitably occurred, in spite of modern equipment, new technologies in shipping and advanced safety precautions. Hence, an analysis of shipping accidents is vital to prevent possible accidents [6]. Goulielmos and Giziakis [7] evaluated the International Safety Management (ISM) code by the fundamentals of the complexity theory for marine accident prevention. Akyuz and Celik [8] utilized a human factor analysis and classification system (HFACS), combined with a cognitive map in modelling human error in marine accident analysis and prevention. Hänninen [9] discussed the utilization of Bayesian networks in maritime safety modelling for maritime traffic accident prevention benefits and challenges. Parasyris et al. [10] investigated technological improvements on bridge systems, which is a key factor in marine accident prevention. Yukihira et al. [11] conducted surveys with fishermen to analyse and prevent maritime accidents of fishermen, focusing on the Bungo Channel.

In this study, a Web-based GIS (Geographic Information System), which can serve to decrease the number of shipping accidents occurring in the Strait of Istanbul, will be designed, created and published via the internet. ArcGIS Desktop, ArcGIS Server and ArcGIS Online software programs will be used to achieve these processes. ArcGIS for Server allows users to obtain these GIS resources and share them as web services. Web services are easily accessible through the Internet and can be purchased by clients such as mobile phones, tablets, desktop applications, and web applications [12]. In addition, it is aimed at enabling vessels to travel safely in these waters. At the same time, the system aims to lower the number of marine accidents in the Strait of Istanbul.

In this study, previous research papers that have examined shipping accidents which took place in the strait will be considered in detail. Furthermore, some statistics between 2004-2015 relating to different types of marine accidents, such as contact, collision, stranding, fire and breaking-up, which were obtained by the Directorate General of Coastal Safety, will be analysed. Depending on the results from the analysis, there will be some suggestions so as to identify the most convenient points in the strait for safer navigation. To be able to achieve this, a GIS design and application of the Bosphorus was developed and it will be published as a web-based system.

In this study, creating a web-based GIS for safe shipping in Istanbul's Bosphorus Strait, considering the physical and biological components of Coastal Management Systems, is the primary objective. The system created would be beneficial for both military and civil sailors underway. It also includes essential information about berthing factors (anchorage grounds, depth, sedimentation, currents and submerged, etc.) maritime traffic items (traffic separation schemes, traffic 
flow directions), closed areas, points of interests in the sea's surface for both sailing and berthing (lighthouses, buoys, beacons) and points of interest in land (radars, elevation points), which were acquired by digitizing the navigation charts that have been created by the Turkish Naval Forces Office of Navigation, Hydrography and Oceanography.

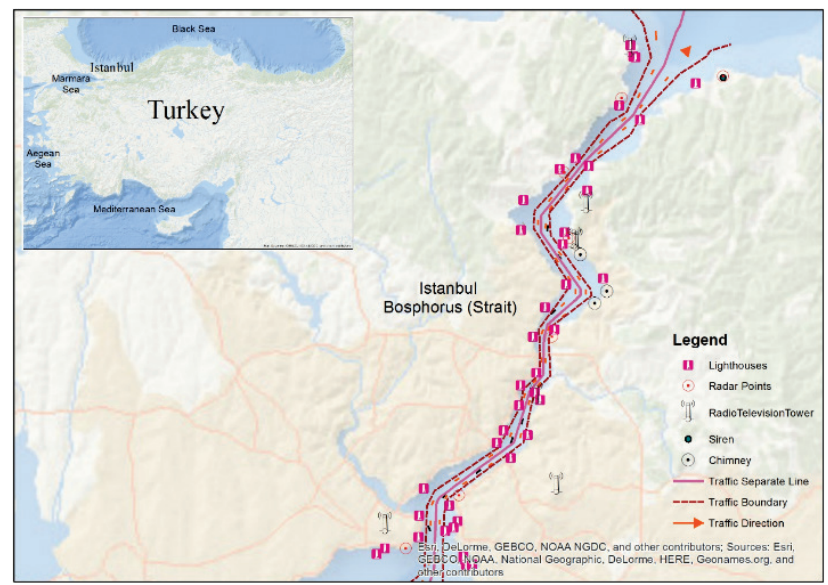

Figure 1 The strait of Istanbul

\section{SHIPPING ACCIDENT}

According to the data obtained by the Republic of Turkey Main Search and Rescue Coordination Centre in the Under-secretariat of Maritime Affairs, there were 1495 marine accidents between 1988 and 2008. The average number of marine accidents occurring in the Turkish sea was reported to be 136. During those years, $22 \%$ of marine accidents (1495 in total) were reported to be stranding [13]. According to the statistics reported by the Directorate General of Coastal Safety, 22\% (62 out of the total) of 272 marine accidents occurring in the Strait of Istanbul between 2004 and 2015 were stranding. Also $70 \%$ of the accidents (190 out of the total) were reported to have happened because of navigation error (Tab. 1). "Traffic Separation Schemes" (TSS) have been founded in the Straits (Istanbul and Canakkale), along with the introduction of the Regulations for Straits, in accordance with the provisions of the "International Regulation for the Prevention of Collision at Sea" (COLREG). The International Maritime Organization Assembly (IMO) approved the TSS in November, 1995, in association with the "Rules and Recommendations on Navigation Through the Istanbul and Canakkale Straits, and the Marmara Sea" [2]. Navigational errors can occur because of overreliance on inaccurate nautical charts; charts based on outdated narrow channels with abrupt and angular windings which make manoeuvrability restricted. Heavy marine traffic is part of the problem in the Straits, along with anchorage contiguous to traffic separation lines and confined marine areas, as well as insufficient sea-room. Shoals, reefs and wrecks can be added to the list of conditions, called "Route Conditions" [5].

\subsection{Causes of Shipping Accidents}

Different causes lead to shipping accidents. These can be categorized into natural conditions, technical failures, route conditions, ship-related factors, human or personal errors and cargo-related factors. There are no certain places, times or conditions for shipping accidents. They may occur in daytime or at night, in clear weather or restricted visibility, in narrow straits, canals, inland waterways, coastal waters or on the high seas and can even be due to defective or off-station navigational marks. Judging distances in daytime is easy. Contrary to this, it is quite difficult to judge distances and estimate the visibility at night. Hence, navigation at night needs some appropriate care, since there are areas which are bright but have scattered background lighting from the shore which can result in confusion. As a result, there is a reduction in the visibility of the lights. Other reasons for taking especial care are sailing lights, which are almost invisible, and unlit hazards affecting navigational safety [5]. The lights of the Strait of Istanbul can only be seen up to 1.9 nautical miles at night, even though their nominal range is generally eight nautical miles. The reason for this is the background light from restaurants and residential areas, etc. Yet, the background lighting in the strait sometimes makes the navigation lights of both small boats and big vessels invisible. As a result, they are first identified by their silhouette against the shore lights. The number of shipping accidents occurring in darkness in the Bosphorus was reported to be almost twice the number of those happening in daytime. Therefore, darkness is an important risk factor for shipping accidents in the Bosphorus [14]. In the Bosphorus, there are two main factors which result in marine accidents: daily current change is the first; second is the large navigation alterations which have to be made with, or against, the main current by vessels and can lead to some hardships. It is very common for vessels to have accidents when they take sharp turns; they lose their manoeuvrability. In the Istanbul and Canakkale Straits, Yenikoy and Umuryeri are two risky areas, respectively. Most of the stranding and grounding accidents have happened there since vessels have to make sharp turns (800 at Yenikoy, 700 at Umuryeri). The Traffic Separation Scheme (TSS) has reported that more than half of the grounding and stranding incidents in the Bosphorus have taken place in Yenikoy and Umuryeri. According to the report by TSS, 26 casualties occurred in Yenikoy and Umuryeri out of the total of 45. Different types of marine accidents which total 461 (i.e. 209 collisions, 138 groundings, 77 stranded, 28 fires/explosions and 9 others, such as rudder blockage, vessels listing or engine breakdowns), happened at these critical points between 1953 and 2002. As stated, the majority of the incidents were collisions. 82 shipping accidents have been reported since 1994 after TSS was officially implemented. These 82 incidents have been mostly grounding/stranding. 55 percent of all incidents in the Bosphorus are grounding and stranding. Currents, sharp turns and darkness are the main risk factors for these two types of incident in the Bosphorus [14].

\subsection{Analysis of Shipping Casualties}

Tab. 1 shows all the data belonging to marine accidents between 2004 and 2015. The data was obtained from the Directorate General of Coastal Safety. 


\begin{tabular}{|c|c|c|c|c|c|c|c|c|}
\hline Location & Direction & 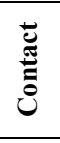 & 递 & 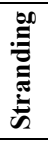 & : & 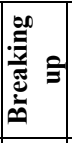 & $\stackrel{\bar{\pi}}{\stackrel{5}{*}}$ & 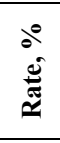 \\
\hline Anadolu hisari & Bosphorus & & & 1 & & & 1 & 0.4 \\
\hline Anadolu Kavağ 1 & Bosphorus & & & 1 & & & 1 & 0.4 \\
\hline Bebek & Bosphorus & 3 & & & & & 3 & 1.1 \\
\hline Beşiktaş & Bosphorus & 1 & & & & & 1 & 0.4 \\
\hline Beykoz & Bosphorus & & & 1 & & & 1 & 0.4 \\
\hline Çalı Burnu & Bosphorus & 1 & & & & & 1 & 0.4 \\
\hline Garipçe & Bosphorus & & & & 1 & & 1 & 0.4 \\
\hline H.Paşa Port Exit & Bosphorus & 3 & 2 & 3 & & & 8 & 2.9 \\
\hline Kandilli & Bosphorus & 5 & 1 & 2 & & & 8 & 2.9 \\
\hline Kanlica & Bosphorus & 1 & & & & & 1 & 0.4 \\
\hline Keçilik Bay & Bosphorus & & 1 & & & & 1 & 0.4 \\
\hline Kirec Cape & Bosphorus & & & 1 & & & 1 & 0.4 \\
\hline Mehmetçik Cape & Bosphorus & 1 & & & & & 1 & 0.4 \\
\hline Acar Cape & Bosphorus & & & 1 & & & 1 & 0.4 \\
\hline Ortaköy & Bosphorus & & & 2 & & & 2 & 0.7 \\
\hline R.Hisarı & Bosphorus & 1 & & & & & 1 & 0.4 \\
\hline Saray Cape & Bosphorus & 3 & 3 & & 1 & & 7 & 2.6 \\
\hline Sarıyer & Bosphorus & 1 & & 1 & & & 2 & 0.7 \\
\hline Umur Yeri Bank1 & Bosphorus & & & 11 & & & 11 & 4.0 \\
\hline Yeniköy & Bosphorus & 2 & & 5 & & & 7 & 2.6 \\
\hline Ahırkapı Demir & Southern & 117 & 13 & 8 & 4 & & 142 & 52.2 \\
\hline Balıkçı Island & Southern & & & 3 & & & 3 & 1.1 \\
\hline $\begin{array}{l}\text { Bosphorus } \\
\text { Southern }\end{array}$ & Southern & 1 & 4 & & & & 5 & 1.8 \\
\hline Büyük Ada & Southern & & & 1 & & & 1 & 0.4 \\
\hline Dilek Kayalığ & Southern & & & 6 & & & 6 & 2.2 \\
\hline Eşek Adası & Southern & & & 1 & & & 1 & 0.4 \\
\hline Fenerbahçe & Southern & & 1 & & & & 1 & 0.4 \\
\hline Kadikoy & Southern & & 3 & & 2 & & 5 & 1.8 \\
\hline Kartal Demir & Southern & 7 & 2 & 1 & & 1 & 11 & 4.0 \\
\hline Marmara Denizi & Southern & & 2 & & & & 2 & 0.7 \\
\hline Zeyport & Southern & 2 & 1 & & & & 3 & 1.1 \\
\hline $\begin{array}{l}\text { Boğaz Kuzey } \\
\text { Giriși }\end{array}$ & Northern & & 1 & & & & 1 & 0.4 \\
\hline Güvem Burnu & Northern & & & 2 & & & 2 & 0.7 \\
\hline Şile & Northern & 1 & & 1 & & & 2 & 0.7 \\
\hline Türkeli & Northern & & 3 & & 2 & 2 & 7 & 2.6 \\
\hline Türkeli Demir & Northern & 7 & & 10 & 1 & 2 & 20 & 7.4 \\
\hline
\end{tabular}

190 shipping accidents out of 272 in the Bosphorus, between 2004 and 2015, were reported to have stemmed from navigation error, based upon the official reports (Tab. 2).

\begin{tabular}{|c|c|c|c|c|c|c|}
\hline 竧 & ن & 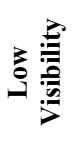 & 童 & 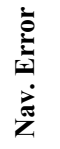 & $\stackrel{\grave{\Xi}}{\stackrel{\Xi}{0}}$ & 苞 \\
\hline Contact & 35 & 0 & 10 & 112 & 0 & 157 \\
\hline Collision & 2 & 2 & 0 & 33 & 0 & 37 \\
\hline Stranding & 7 & 0 & 10 & 45 & 0 & 62 \\
\hline Fire & 0 & 0 & 0 & 0 & 11 & 11 \\
\hline Breaking up & 3 & 0 & 0 & 0 & 2 & 5 \\
\hline Total & 47 & 2 & 20 & 190 & 13 & 272 \\
\hline
\end{tabular}

GIS for the Bosphorus would decrease the number of accidents stemming from navigation error. The proposed system for the Bosphorus would determine the location of a vessel in the Bosphorus. The system would also let the user query the sea's depth at the vessel's location and the accuracy of the route the vessel has been following in the Bosphorus.

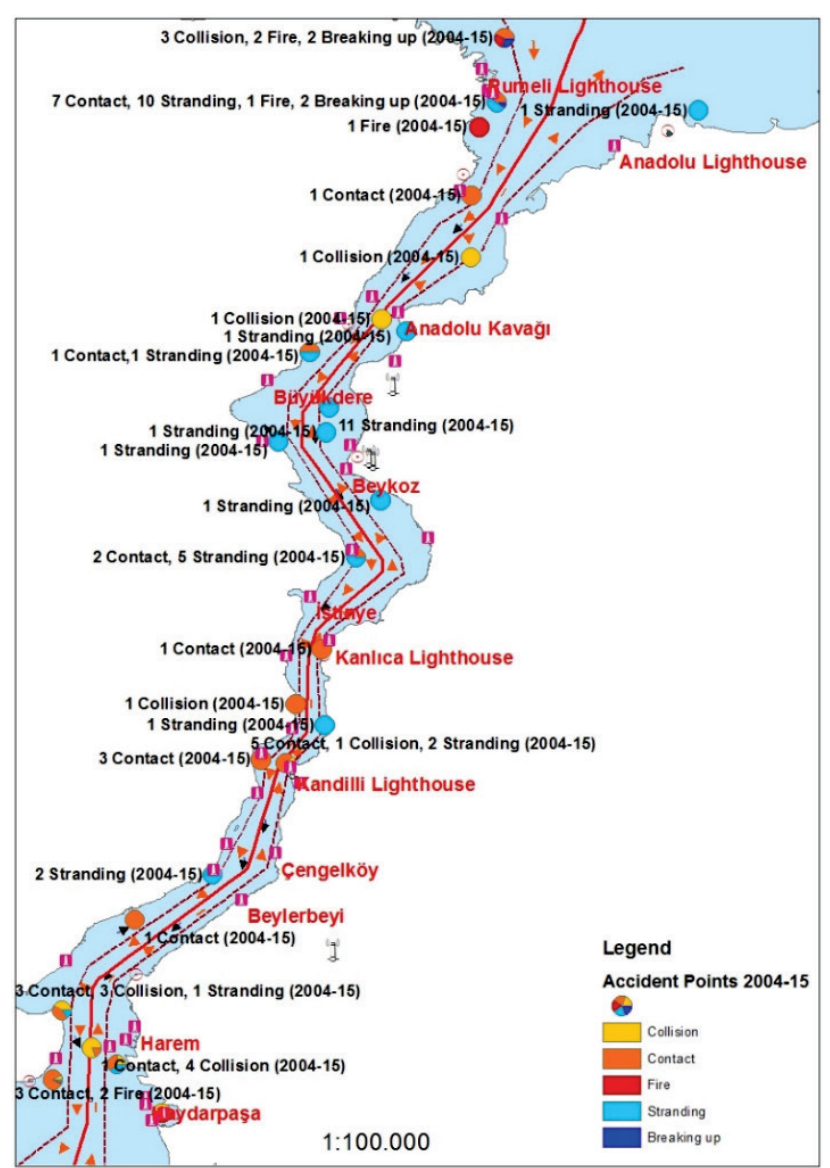

Figure 2 Marine Accidents in the Strait of Istanbul (2004-2015)

\section{WEB-BASED GIS}

Web-based systems comprise at least two computers connected in a client/server-configuration. They communicate through Internet technology, exchange geodata and offer GIS functionality. In the simplest case, Web-GIS-technologies utilize static maps, linked with graphics and HTML [15]. In the system, the server is considered as a web application server and client as a web browser, a desktop application or a mobile application (Fig. 3).

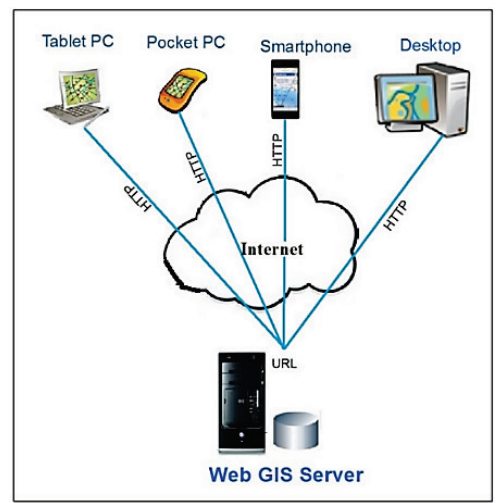

Figure 3 Web GIS Server [20]

GIS analysis needs client-server architecture in a web-based GIS. The client and the server are responsible for the necessary processes in a web-based GIS. The server provides data and analysis functions for the client. Completing the request, transmitting the response or providing data and analysis functions to the client are the 
functions of the server $[16,17]$. Web-based applications are free, online tools that run within a website [18]. A web-based platform provides collaboration and data sharing between specialists, planning agencies, citizens and private entities [19].

\section{SYSTEM DESIGN AND APPLICATION FOR WEB BASED GIS}

Software and hardware needed for the system have been researched. It is required hardware which has a highspeed processor (Intel ${ }^{\circledR}$ Core TM i7) and high RAM capacity. A computer with a processor of "Intel Core i7930, $2.80 \mathrm{GHz}$ " and RAM of "22.0 GB" was chosen. The operating system, Windows Server 2012 R2, which was also suited for the purpose, was set up.

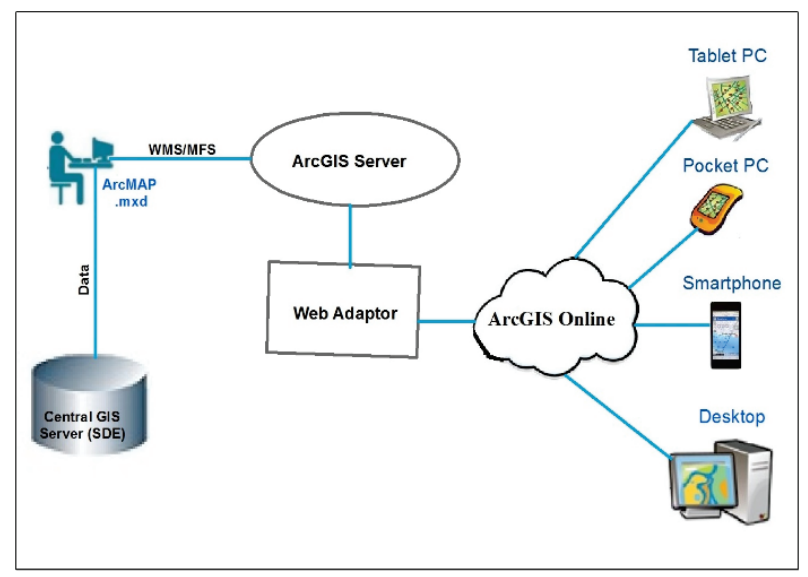

Figure 4 ArcGIS Online [21]

Table 3 Layers properties

\begin{tabular}{|l|c|l|}
\hline \multicolumn{1}{|c|}{ Layer Name } & Layer Type & \multicolumn{1}{c|}{ Layer Alias } \\
\hline Lighthouse & Point & Lighthouse \\
\hline BuoysAndBeacons & Point & Buoys and Beacons \\
\hline AccidentPoints2004_15 & Point & Accident Points 2004_15 \\
\hline BosphorusDepths & Point & Bosphorus Dephts \\
\hline LandElevationPoint & Point & Land Elevation Point \\
\hline RadarPoints & Point & Radar Points \\
\hline RadioTelevisionTower & Point & Radio Television Tower \\
\hline FogSignals & Point & Fog Signals \\
\hline NatureOfSeabed & Point & Nature of Seabed \\
\hline FerryQuay & Point & Ferry Quay \\
\hline RocksWrecksObstruction & Point & Rocks Wrecks Obstruction \\
\hline TrafficSeparateLine & Line & Traffic Separate Line \\
\hline TrafficBoundary & Line & Traffic Boundary \\
\hline TrafficDirection & Line & Traffic Direction \\
\hline SubmarineCables & Line & Submarine Cables \\
\hline MilitaryLine & Line & Military Line \\
\hline ForbiddenLine & Line & Forbidden Line \\
\hline DirectionOfCurrent & Line & Direction of Current \\
\hline TupeAnd Mamararay & Line & Tupe and Mamararay \\
\hline GSIsland & Polygon & GS Island \\
\hline CableInTheSeaArea & Polygon & Cable in the Sea Area \\
\hline MilitaryTraining & Polygon & Military Training \\
\hline ForbiddenArea & Polygon & Forbidden Area \\
\hline AnchoringArea & Polygon & Anchoring Area \\
\hline & &
\end{tabular}

In the system, ArcGIS 10.3.1 Desktop software was used. The project database was created through ArcCatalog in the software and the layers were arranged by digitizing through ArcMap. The project services were performed through ArcGIS Server. ArcGIS Online software program was used while publishing and so arrangements of the queries have been achieved (Fig. 4).
WepAppBuilder for ArcGIS enables the user to query all the necessary data. Thus, the integrated systems' approach mentioned above creates a user-friendly environment [21].

\subsection{Layer Design}

In this study, 11 point layers, 8 polyline layers and 5 polygon layers have been designed. Tab. 3 shows the layer properties of designed layers.

Some of the layers obtained by digitizing the data are shown with their symbols in Fig. 5.

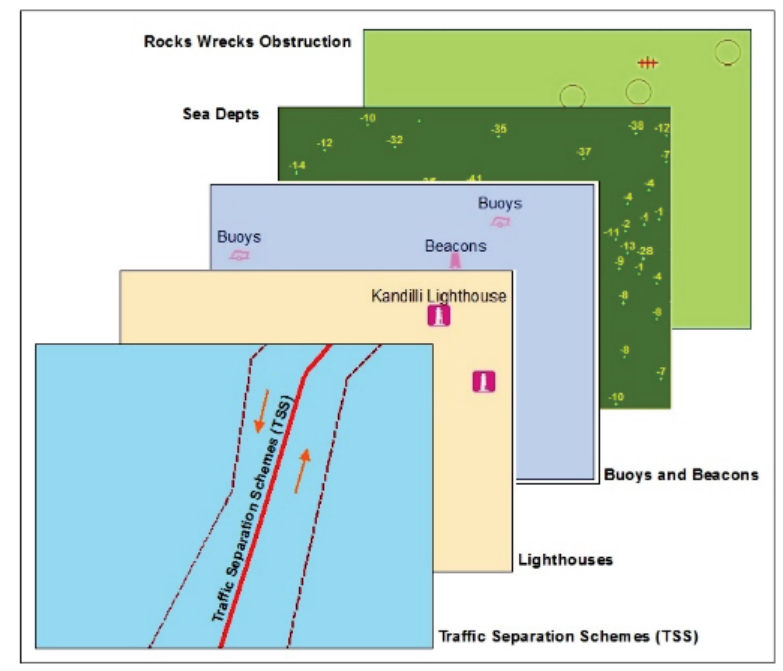

Figure 5 Some of the digitized layers

Table 4 Attributes of AccidentPoints2004_15

\begin{tabular}{|c|c|c|c|c|}
\hline \multicolumn{5}{|l|}{ Layer Design } \\
\hline Feature Class Name & Layer Name & \multicolumn{3}{|c|}{ Geometry Type } \\
\hline AccidentPoints2004_15 & $\begin{array}{l}\text { Accident } \\
\text { Points } \\
2004-15\end{array}$ & \multicolumn{3}{|c|}{ Point } \\
\hline \multicolumn{5}{|l|}{ Attribute Design } \\
\hline Name & Alias & Type & Length & $\begin{array}{c}\text { Sample } \\
\text { Data }\end{array}$ \\
\hline TypeOfAccident & $\begin{array}{c}\text { Type of } \\
\text { Accidents }\end{array}$ & Text & 50 & $\begin{array}{c}3 \text { Contact } \\
(2004- \\
15) \\
\end{array}$ \\
\hline CollisionNumber & $\begin{array}{l}\text { Collision } \\
\text { Number }\end{array}$ & Number & Short & 0 \\
\hline ContactNumber & $\begin{array}{l}\text { Contact } \\
\text { Number }\end{array}$ & Number & Short & 3 \\
\hline StrandingNumber & $\begin{array}{l}\text { Stranding } \\
\text { Number }\end{array}$ & Number & Short & 0 \\
\hline FireNumber & $\begin{array}{c}\text { Fire } \\
\text { Number }\end{array}$ & Number & Short & 0 \\
\hline BreakingUpNumber & $\begin{array}{l}\text { Breaking up } \\
\text { Number }\end{array}$ & Number & Short & 0 \\
\hline LocationAccident & $\begin{array}{l}\text { Location } \\
\text { Accident }\end{array}$ & Text & 50 & Bebek \\
\hline RateAccident & $\begin{array}{c}\text { Rate } \\
\text { Accident }\end{array}$ & Number & Float & 0.029 \\
\hline DirectionAccident & $\begin{array}{l}\text { Direction } \\
\text { Accident }\end{array}$ & Text & 50 & Bebek \\
\hline TotalAccident & $\begin{array}{c}\text { Total } \\
\text { Accident }\end{array}$ & Number & Short & 3 \\
\hline
\end{tabular}

\subsection{Design of the Attributes in the System}

The design of the attributes has been created to fulfil the needs expected from the system. Tabs. 4 and 5 show the attributes and features belonging to AccidentPoints, 
2004-2015, and the lighthouse layers by means of sample data input.

Table 5 Attributes of Lighthouses

\begin{tabular}{|c|c|c|c|c|}
\hline \multicolumn{5}{|l|}{ Layer Design } \\
\hline Feature Class Name & Layer Name & \multicolumn{3}{|c|}{ Geometry Type } \\
\hline Lighthouses & Lighthouses & \multicolumn{3}{|c|}{ Point } \\
\hline \multicolumn{5}{|l|}{ Attribute Design } \\
\hline Name & Alias & Type & Length & $\begin{array}{l}\text { Sample } \\
\text { Data }\end{array}$ \\
\hline LighthouseName & $\begin{array}{l}\text { Lighthouse } \\
\text { Name }\end{array}$ & Text & 75 & $\begin{array}{l}\text { Rumeli } \\
\text { Lighthouse } \\
\text { (Türkeli) }\end{array}$ \\
\hline Properties & Properties & Text & 25 & $\begin{array}{c}\mathrm{FI}(2) 12 \mathrm{~s} 58 \\
\mathrm{~m} 18 \mathrm{M}\end{array}$ \\
\hline Label & Label & Text & 25 & Horn 20s \\
\hline Information & Information & Text & 50 & $\begin{array}{l}\text { Horn 20s } \\
\text { (Fog light) }\end{array}$ \\
\hline $\begin{array}{l}\text { DaylightPhotoLighthou } \\
\text { se }\end{array}$ & $\begin{array}{l}\text { Daylight } \\
\text { Photo of } \\
\text { Lighthouse }\end{array}$ & Text & 275 & $1 *$ \\
\hline $\begin{array}{l}\text { ZoomInDaylightPhotoL } \\
\text { ighthouse }\end{array}$ & $\begin{array}{l}\text { Zoom In } \\
\text { Daylight } \\
\text { Photo }\end{array}$ & Text & 175 & $2 *$ \\
\hline $\begin{array}{l}\text { DateDaylightPhotoLigh } \\
\text { thouse }\end{array}$ & $\begin{array}{l}\text { Date } \\
\text { Daylight } \\
\text { Photo }\end{array}$ & Date & & 09-Nov-11 \\
\hline $\begin{array}{l}\text { YesNoDaylightPhotoLi } \\
\text { gthhouse }\end{array}$ & $\begin{array}{l}\text { YES/NO } \\
\text { Daylight } \\
\text { Photo of } \\
\text { Ligthhouse }\end{array}$ & Text & 3 & YES \\
\hline NightPhotoLighthouses & $\begin{array}{l}\text { Night Photo } \\
\text { of } \\
\text { Lighthouse }\end{array}$ & Text & 275 & $2 *$ \\
\hline $\begin{array}{l}\text { ZoomInNightPhotoLigh } \\
\text { thouse }\end{array}$ & $\begin{array}{c}\text { Zoom In } \\
\text { Night Photo }\end{array}$ & Text & 175 & $3 *$ \\
\hline $\begin{array}{l}\text { DateNightPhotoLightho } \\
\text { use }\end{array}$ & $\begin{array}{l}\text { Date Night } \\
\text { Photo }\end{array}$ & Date & & 19-Nov-12 \\
\hline $\begin{array}{l}\text { YesNoNightPhotoLight } \\
\text { house }\end{array}$ & $\begin{array}{l}\text { YES/NO } \\
\text { Night Photo } \\
\text { of } \\
\text { Lighthouse }\end{array}$ & Text & 3 & YES \\
\hline \multicolumn{5}{|c|}{$\begin{array}{c}\text { 1*<a } \\
\text { href="http://www.gis.yildiz.edu.tr/ wwwgis/BosphorusPhotos/Lightho } \\
\text { use/Rumeli.jpg" target=blank }><\text { img } \\
\text { src="http://www.gis.yildiz.edu.tr/ wwwgis/BosphorusPhotos/Lightho } \\
\text { use/Rumeli.jpg"border=0 alt="Zoom In" title="Zoom In" } \\
\text { width="150"height="100"> }\end{array}$} \\
\hline \multicolumn{5}{|c|}{$\begin{array}{c}2^{*}<\mathrm{a} \\
\text { href="http://www.gis.yildiz.edu.tr/ } \sim \text { wwwgis/BosphorusPhotos/Lightho } \\
\text { use/Rumeli.jpg" target="_blank" }>\text { Click }<\text { a }>\end{array}$} \\
\hline \multicolumn{5}{|c|}{$\begin{array}{c}3^{*}<\mathrm{a} \\
\text { href="http://www.gis.yildiz.edu.tr/ wwwgis/BosphorusPhotos/Lightho } \\
\text { use/RumeliN.jpg" target=blank><img } \\
\mathrm{src=}=\text { "http://www.gis.yildiz.edu.tr/ } \sim \text { wwwgis/BosphorusPhotos/Lightho } \\
\text { use/RumeliN.jpg"border=0 alt="Zoom In" title="Zoom In" } \\
\text { width="150"height="100" }>\end{array}$} \\
\hline $\begin{array}{r}\text { href="http://www.gis.yil } \\
\text { use/Rumelis } \\
\end{array}$ & $\begin{array}{c}4^{*}<\mathrm{a} \\
\text { iz.edu.tr/ } \sim \mathrm{ww} \\
\text {.jpg" target }="\end{array}$ & $\begin{array}{l}\text { vgis/B } \\
\text { blank' }\end{array}$ & horus & otos/Lightho \\
\hline
\end{tabular}

\subsection{Digitizing}

It was considered how the data used for the system would be obtained and the digital data of the sea maps including the Bosphorus were proposed. The Office of Navigation, Hydrography and Oceanography has been responsible for the production of the sea maps of Turkey. This office has produced several sea maps in different scales by dividing the Bosphorus into various areas (Tab. $6)$. These maps have also started to be used as charts. For this study, the maps needed for the system were purchased from the Office of Navigation, Hydrography and Oceanography. The maps have been scanned by high definition scanners. These maps consist of some details which makes transportation in the Bosphorus easy and safe. It is possible to include these details as geographic data type point, line and polygon. Grid points were used as reference points and details were digitized on the designed layers [22].

Table 6 Bosphorus Maps
\begin{tabular}{|l|c|c|}
\hline \multicolumn{1}{|c|}{ Location } & Production Date & Scale \\
\hline Bosphorus North & 1993 & $1 / 50000$ \\
\hline Bosphorus Middle & 1996 & $1 / 30000$ \\
\hline Bosphorus South & 1999 & $1 / 12500$ \\
\hline
\end{tabular}

\section{QUERIES}

Some queries can be achieved, in order to obtain the data needed for the system. Obtaining different queries in the system for different purposes could be achieved when required.

\subsection{Position Data}

Both position data and aids of navigation data can be acquired by those who are in charge of the navigation of vessels through mobile phones, whilst navigating. Images in Fig. 6 were obtained from smart mobile phones.

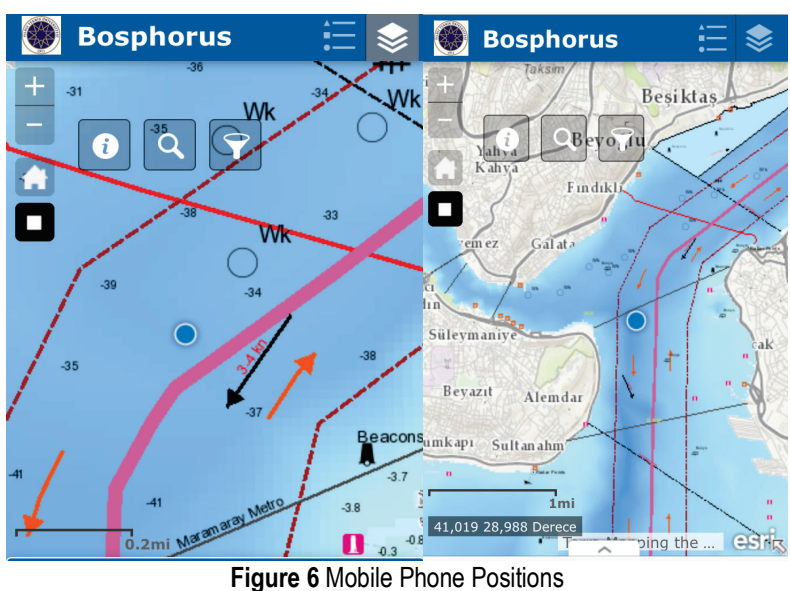

\subsection{Shipping Casualties}

Web-based GIS contributes to presenting the query result obtained through GPS. Fig. 7 shows the analysis results of marine accidents which occurred in the Strait of Istanbul between 2004 and 2015. These results have been provided by the query through Web-based GIS and they will help the captains of vessels cruising in the Strait of Istanbul to be more cautious, so as not to cause any marine accidents.

\subsection{The Query of Lighthouses and Buoys}

A ship's built-in navigation system makes it possible to navigate through its planned route. The location of the lighthouses, buoys and beacons can be seen on the map in these navigation systems. The location of lighthouses and buoys can also be queried using the developed Web-based GIS. Lighthouses, buoys and beacons are fundamentally 
important for vessels to navigate safely. In Fig. 8, the locations of lighthouses can be viewed.

For the user, the internet and the receiver connected to the internet (Tablet PC, Pocket PC, Smartphone or Desktop) will be able to fulfil the requirements.

The captain who was interviewed for the study had reported that obtaining the data, including the locations of the lighthouses and buoys, would enable the captains of vessels cruising in the Bosphorus to identify the coordination, considering the locations of the lighthouses. This is especially crucial for the captains who navigate in the Bosphorus for the first time. According to research done by Akten, it was stated that one of the factors leading to marine accidents was unidentified lighthouses [5].

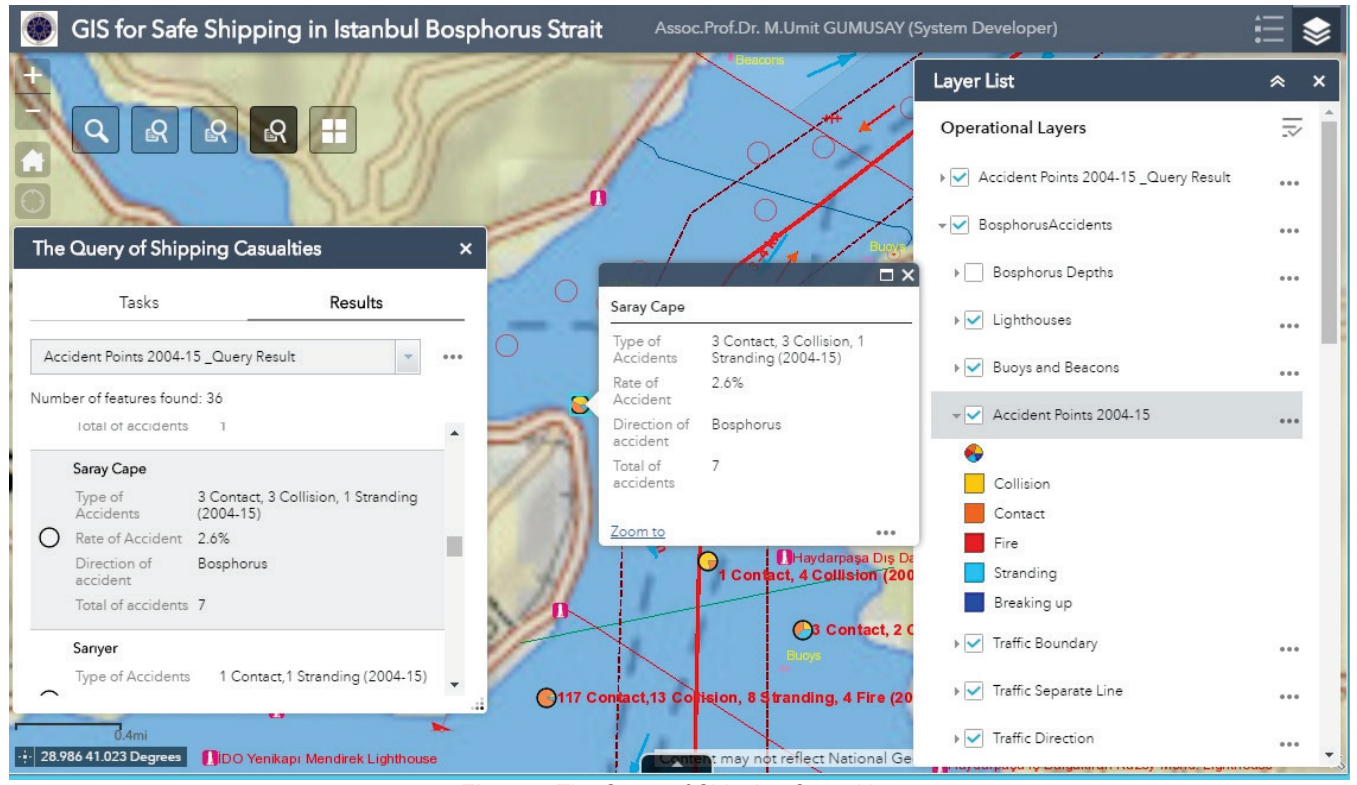

Figure 7 The Query of Shipping Casualties

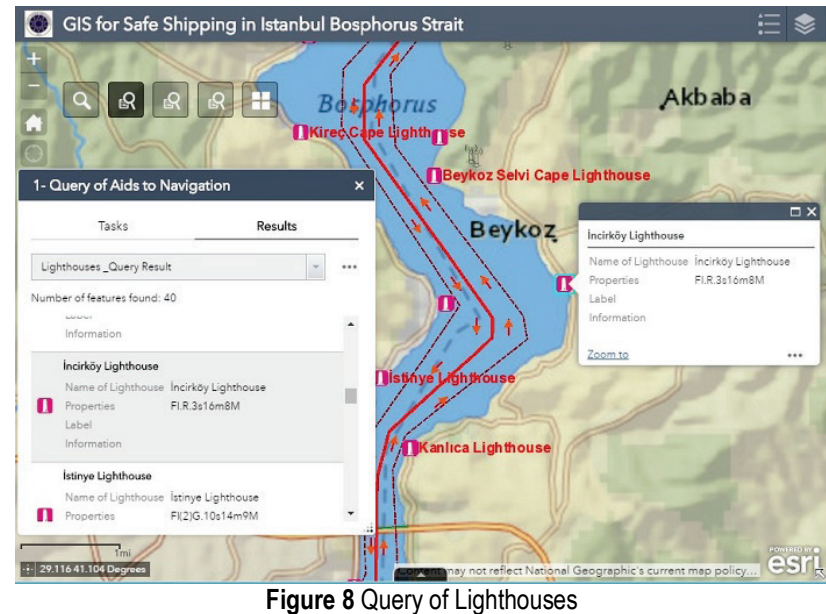

Figure 8 Query of Lighthouses

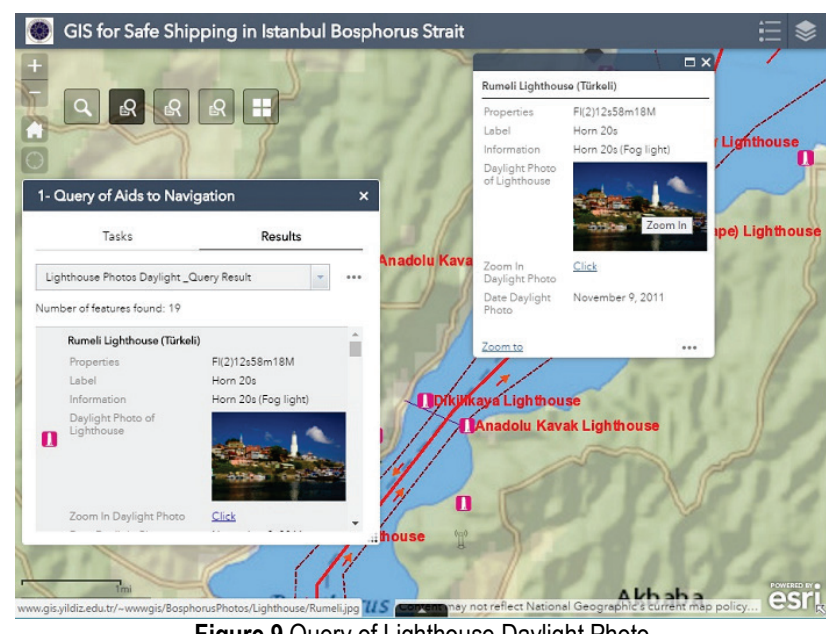

Figure 9 Query of Lighthouse Daylight Photo

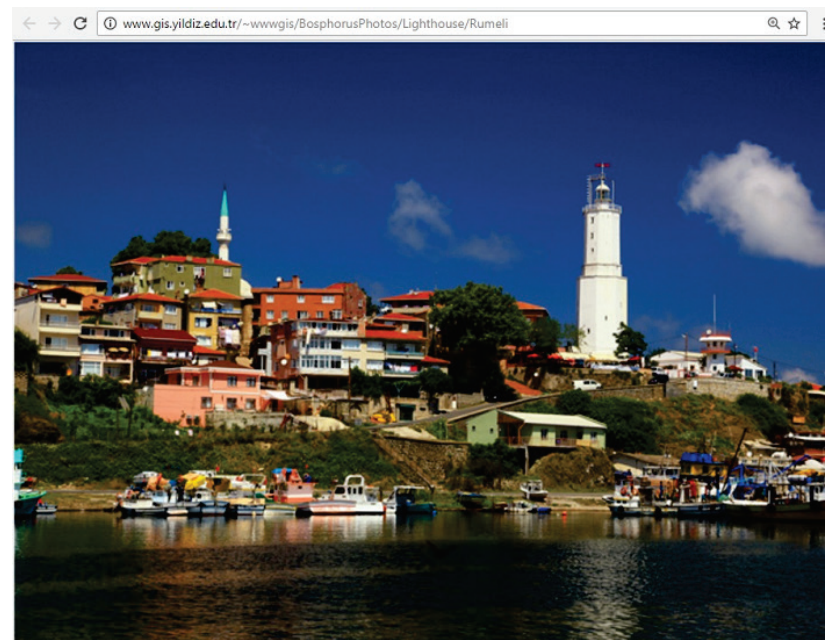

Figure 10 Lighthouse Daylight Photo

The Bosphorus GIS could enable the users to query the locations of lighthouses, buoys, radars, etc. which can be shown in different colours and dimensions on the maps. That also enables all vessels to travel in safety on the Bosphorus. With the proposed Web-based GIS system, one can access the daytime (Fig. 9) and nighttime photos (Fig.10) of the lighthouses, taken from the sea. In this way, vessels can have more accurate visibility through those lighthouses, which means safer crossings through the Bosphorus.

The majority of shipping accidents have been reported as happening in darkness. The main reason for this is the lack of visibility of the lighthouses because of the lights of the inland structures. One of the solutions to prevent this problem is to take daytime and night-time 
photos of the lighthouses with high resolution cameras. As a result, lighthouses which can't be clearly viewed at night, can be more noticeable by drawing their photos in different colours (Fig. 11 \& Fig. 12). Following that, the photos are stored on computers. Through GIS created for the Bosphorus, the daytime and night-time photos of the lighthouses can be viewed on a computer screen having a coding system for their attributes, created on the lighthouses' layer in the system.
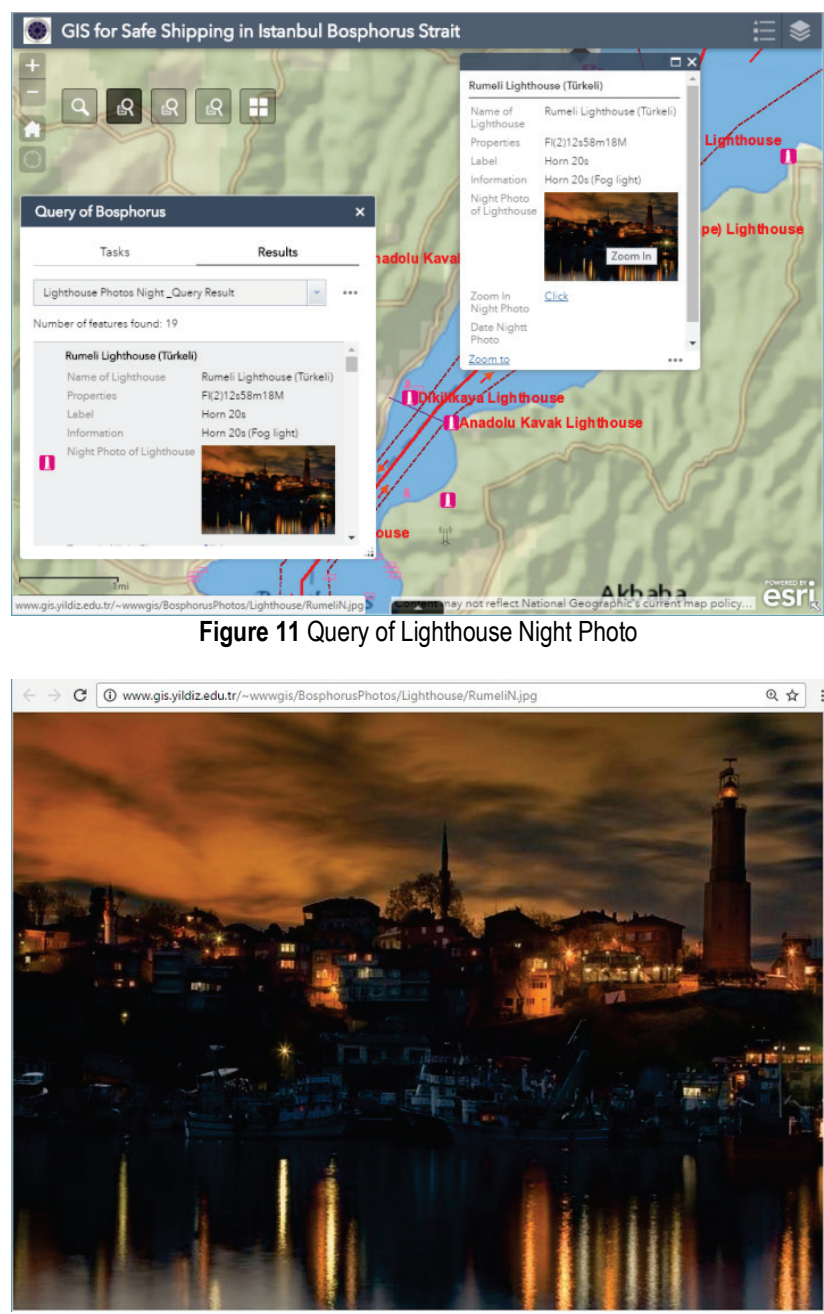

Figure 12 Lighthouse Night Photo

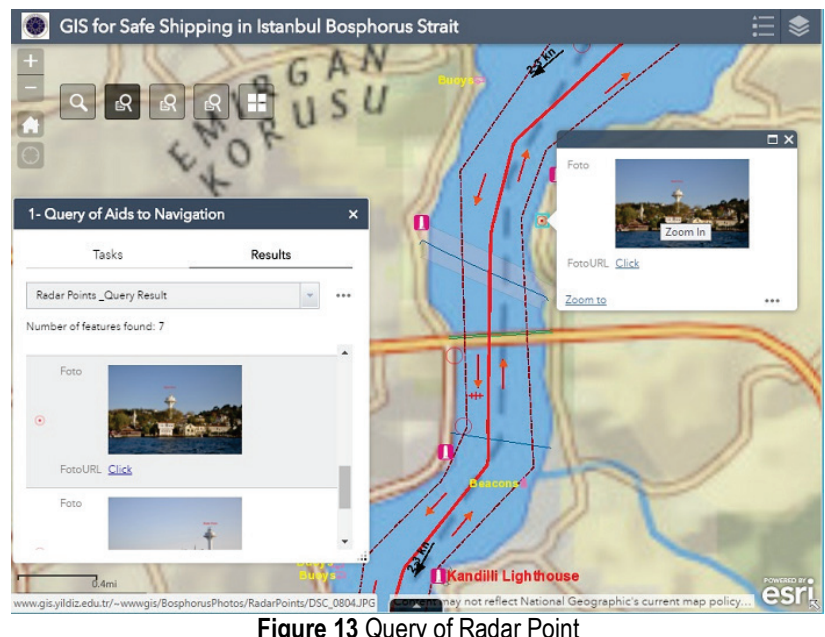

Buoys and beacons are considered crucial for safe navigation in the sea and they have similar characteristics to lighthouses. The photographs of them, which were taken from the sea, can be queried in the system.

\subsection{Radar Points}

The sea views of Radar Points can be queried in the system (Fig. 13 \& Fig. 14).

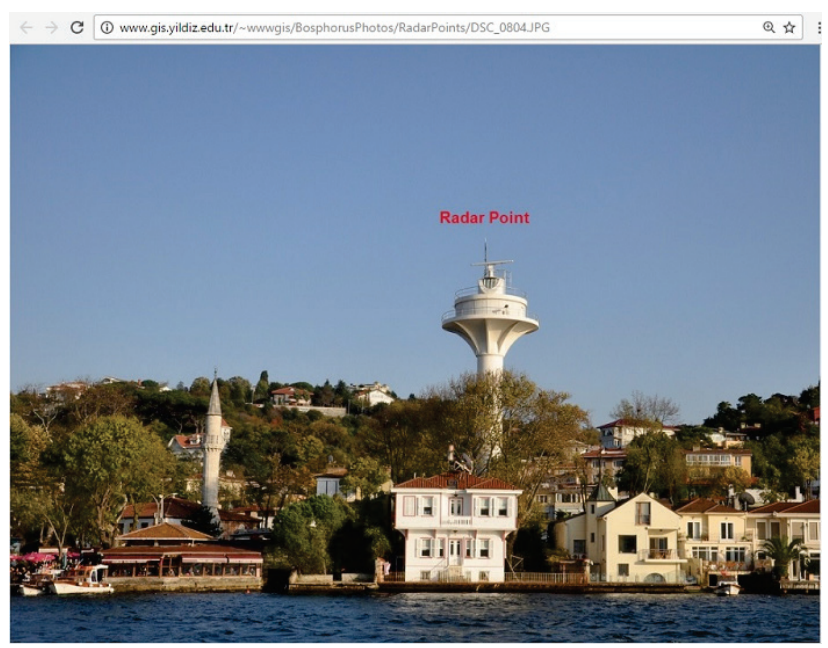

Figure 14 Query of Radar Photo

\subsection{Rocks, Wrecks and Obstructions}

Through the proposed system, the user will be able to notice obstructions, such as rocks and wrecks in the Bosphorus, whilst cruising (Fig. 15)

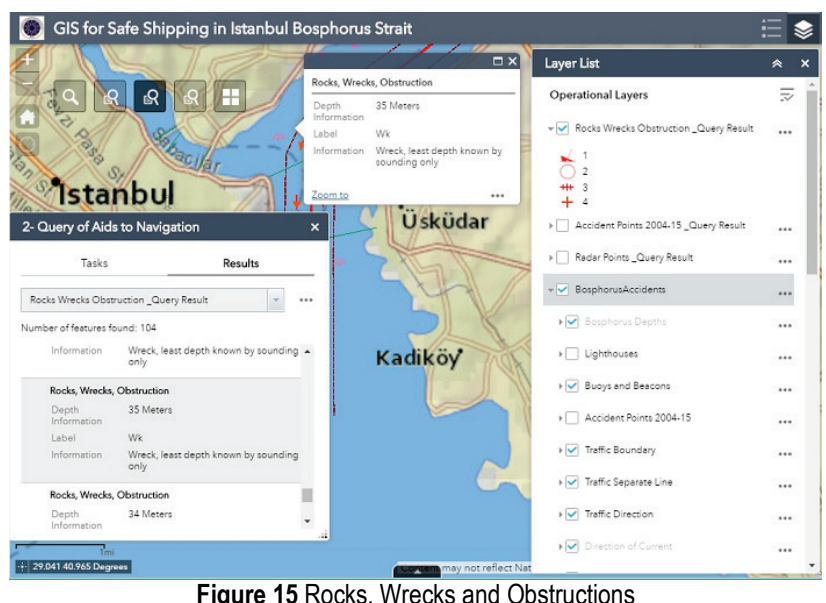

\subsection{The Importance of Depth Points}

The most common type of shipping/marine accidents seem to be stranding. Obtaining essential data about the sea depth at certain points is undoubtedly crucial, in order to prevent stranding accidents. Sea depth points are identified when the data is digitized from 2341 points, through bathymetric measurements in the Bosphorus; the average depth was measured to be 30.43 meters. These measurements are fundamentally important for all vessels crossing the Bosphorus, to travel safely when navigated accurately.

Sea depths are considered crucial for high tonnage vessels, so as not to become involved in any stranding accidents. As the percentage for this sort of accident has 
been reported to be $22 \%$, it is extremely important for vessels, considering the sea's depth has a great impact on choosing the correct route. In the proposed system, the query has been performed for sea depths between -1 and 25 meters (Fig. 16). The depth levels are shown in different tones of blue on a raster map, created using the depth data (Fig. 17).

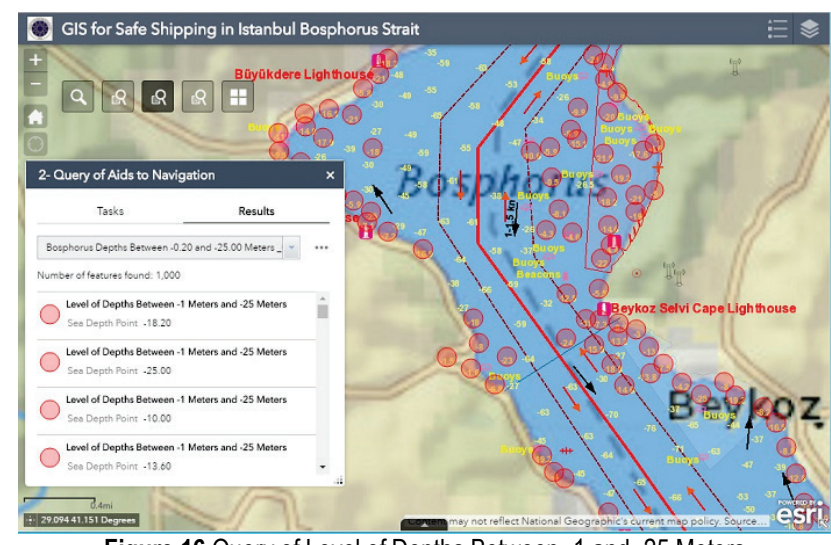

Figure 16 Query of Level of Depths Between -1 and -25 Meters

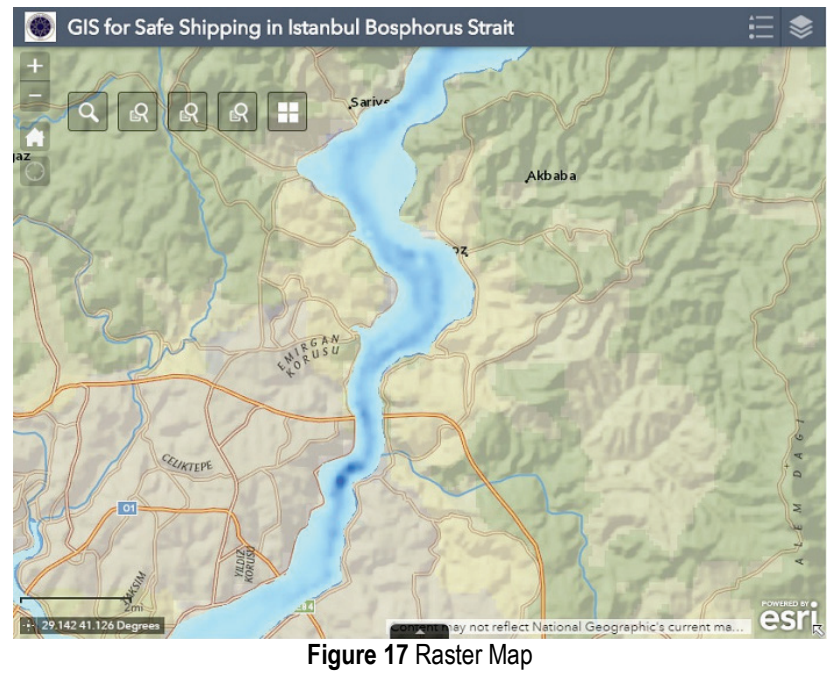

\section{ADVANTAGES OF THE CREATED SYSTEM}

The system can be used whenever needed, at any time during daytime and night-time.

The system can be used without special equipment. Just a mobile application, (Tablet PC, Pocket PC and Smartphone) or a computer with an internet connection can serve the aim.

The night and daytime photos of the lighthouse and beacons are available in the system. The advantage of accessing them while coursing/cruising.

Being able to query the rocks, wrecks and obstructions in the sea and identify their locations.

Being able to show the sea depth points at different intervals (between -1 meter and -25 meters).

Being able to determine the sea depth points, which are essential for a vessel's safe navigation through the Bosphorus, by producing coloured raster maps, according to the different sea depth points.

Viewing the areas where shipping accidents have happened and the type of the shipping accidents in the
Bosphorus on the screen, by analysing the data taken from the Directorate General of Coastal Safety.

$\square$ Different scaled layers can be viewed on a smart phone or computer.

The real-time location of vessels can be determined via GPS, available on smart phones or computers.

$\square$ The user will be able obtain a great deal of benefit when using location data, after the layer query in the system.

$\square$ The position of the lighthouse can be viewed on the screen when the user enters the name of the lighthouse into the system.

$\square$ The base map used in the system could be chosen, according to the user's purpose.

\section{RESULTS AND DISCUSSION}

Web-based GIS has been beneficial in our daily lives. The benefits obtained by the web-based GIS in this study will be considered to have started a decrease in the number of shipping accidents in the Bosphorus. Since the system was created in this study, it can enable one to travel safely without a navigation system in the Bosphorus, for the wide use of such a system will spread through support from governmental offices, such as the Directorate General of Coastal Safely.

In this study, it was discussed how crucial the role of the location data has been for vessels. Furthermore, having the location data for the lighthouses and buoys in the sea is especially important while vessels navigate.

\section{Acknowledgements}

Thanks to The Directorate General of Coastal Safety who gave their support in taking pictures along the shoreside and statistical data between 2004 and 2015 which were required for the system to be developed.

\section{REFERENCES}

[1] Usluer, H. B. (2016). Importance of the Marine Science and Charting about Environmental Planning, Management and Policies at the Turkish Straits. European Journal of Sustainable Development Research, 1(1), 16-25.

[2] Köse, E., Basar, E., Demirci, E., Güneroğlu, A., \& Erkebay, S. (2003). Simulation of marine traffic in Istanbul Strait. Simulation Modelling Practice and Theory, 11(7-8), 597608. https://doi.org/10.1016/j.simpat.2003.10.001

[3] Directorate General of Coastal Safety. (2014). The Head of Vessel Traffic and Pilotage Services Department. Retrieved from: http://www.kiyiemniyeti.gov.tr/Default.aspx?pid=23

[4] Ece, N. J. (2012). Analysis of ship accidents in the strait of Istanbul. Dokuz Eylul University Maritime Faculty Journal, 4(2), 1-25.

[5] Akten, N. (2006). Shipping accidents: a serious threat for marine environment. Journal of Black Sea/Mediterranean Environment, 12(3), 269-304.

[6] Tas, A. \& G. Alkan. (2016). Analysis of Grounding Accidents in the Mediterranean and the Aegean Sea Coast of Turkey. II. Proceedings of the Global Conference on Innovation in Marine Technology and the Future of Maritime Transportation, Bodrum, Mugla, Turkey, 290300 .

[7] Goulielmos, A. M. \& Giziakis, C. B. (2002). Marine accident prevention: an evaluation of the ISM code by the 
fundamentals of the complexity theory. Disaster Prevention and Management: An International Journal, 11(1), 18-32. https://doi.org/10.1108/09653560210421673

[8] Akyuz, E. \& Celik, M. (2014). Utilisation of cognitive map in modelling human error in marine accident analysis and prevention. Safety Science, 70, 19-28. https://doi.org/10.1016/j.ssci.2014.05.004

[9] Hänninen, M. (2014). Bayesian networks for maritime traffic accident prevention: Benefits and challenges. Accident Analysis \& Prevention, 73, 305-312. https://doi.org/10.1016/j.aap.2014.09.017

[10] Parasyris, G., Georgoulis, G. L., \& Nikitakos, N. (2010). Technological improvements on bridge systems as a key factor to marine accident prevention. Proceedings of $3^{\text {rd }}$ International Symposium on Ship Operations, Management and Economics, Athens, Greece.

[11] Yukihira, M., Shinoda, T., Sakaide, M., \& Fujimoto, S. (2015). The Sense and Prevention of Maritime Accident of Fishermen, focusing on Bungo Channel. Asia Navigation Conference, Kitakyushu, Japan, 299-306.

[12] Law, D. (2013). ArcGIS for Server 101; Understanding Architecture, Deployment, and Workflows. Retrieved from: http://www.esri.com/ /media/Files/Pdfs/news/arcuser/0313/ arcgis101.pdf

[13] Nas, S. (2011). An Analytical Approach to The Marine Transportation Safety at Gulf of Izmir and a Grounding Accidents Analysis at Yenikale Channel. Dokuz Eylul University Engineering Faculty, Journal of Engineering Sciences, 13(1), 9-21.

[14] Akten, N. (2004). Analysis of Shipping Casualties in the Bosphorus. Journal of Navigation, 57(3), 345-356. https://doi.org/10.1017/S0373463304002826.

[15] Mueckschel, C. \& Köhler, W. (2007). Web based GIS as a Central Tool of an Information System for Interdisciplinary Research Projects. EFITA. 2007, Scotland

[16] ESRI. (2011). GIS in the Web Era. Retrieved from: http://esripress.esri.com/storage/esripress/images/188/1153 91_webgis_chapter01.pdf

[17] Peng, Z. R. (1999). An Assessment Framework for the Development of Internet GIS. Environment and Planning B: Planning and Design, 26(1), 117-132. https://doi.org/10.1068/b260117

[18] DataLab at Tufts University. (2017). Web Based Applications. Retrieved from: https://sites.tufts.edu/datalab/ software-tools/web-based-applications/

[19] Singh, P. S., Chutia, D. \& Sudhakar, S. (2012). Development of a web based GIS application for spatial natural resources information system using effective open source software and standards. Journal of Geographic Information System, 4(3), 261-266. https://doi.org/10.4236/jgis.2012.43031

[20] Fu, P. \& Sun, J. (2010). Web GIS: principles and applications, Esri Press.

[21] Penman, O. \& Irvine L. (2016). Keep It Simple - Web Apps for Non-Developers. ESRI Scottish Conference, Glasgow, Scotland.

[22] Gumusay, M. U., Ozdemir, O., \& Bakirman, T. (2016). Designing and Modelling Coast Management GIS for Bosphorus, XXIII ISPRS Congress, Prague, Czech Republic.

\section{Contact information:}

Mustafa Umit GUMUSAY, Assoc. Prof. Dr.

Yildiz Technical University

Davutpasa, Esenler, 34220, Istanbul, Turkey

gumusay@yildiz.edu.tr 